Working Paper No. 05 - August 2017

SERVANTS OR RIVALS? UNCOVERING THE DRIVERS AND LOGICS OF THE EUROPEAN PARLIAMENT'S DIPLOMACY DURING THE UKRAINIAN CRISIS

Daan Fonck 


\section{SERVANTS OR RIVALS? UNCOVERING THE DRIVERS AND LOGICS OF THE EUROPEAN PARLIAMENT'S DIPLOMACY DURING THE UKRAINIAN CRISIS}

Daan Fonck

Leuven International and European Studies (LINES), University of Leuven 


\section{Table of Contents}

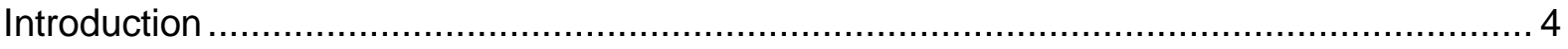

The logics of parliamentary diplomacy: a framework for analysis ..................................... 5

Case-study: the Ukrainian crisis and the Cox-Kwaśniewski mission................................. 7

I. Retracing the origins of the Cox-Kwaśniewski mission ..................................... 8

II. The EPMM's metamorphosis.................................................................. 10

III. The EPMM on the eve of the Vilnius Summit: a pivotal player ........................... 11

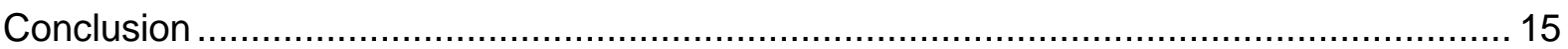

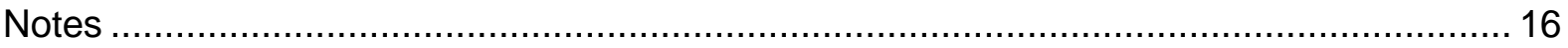

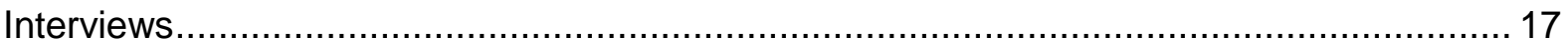

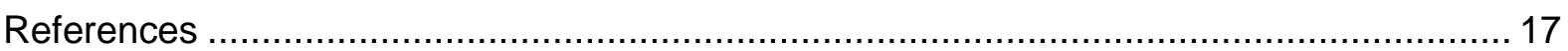




\section{Introduction}

This working paper takes the EP's diplomatic involvement in the 2012-2013 Ukrainian crisis as an empirical puzzle that deserves further scrutiny. In particular, the participation of a parliamentary actor in high-level diplomatic games triggers the question of how such involvement relates to official 'executive' diplomacy.

On the $27^{\text {th }}$ November 2013, the Vilnius Eastern Partnership (EaP) Summit took place in a rather strained and depressed atmosphere. What was supposed to become an event that would give new impetus to the European Union's (EU) Eastern Partnership process turned into diplomatic loss of face for Brussels. A few days before the summit, the Ukrainian government unexpectedly announced it would halt the preparation process for signing a long negotiated and awaited Association Agreement (AA) with the EU, signalling the country's leadership unwillingness to give in to EU-requested rule of law reforms.

What appears to have gone under the radar, however, is that European Parliament (EP) was heavily involved in the effort to convince Kyiv to carry through EU-demanded justice reforms, most notably with regard to finding a solution for the imprisonment of former PrimeMinister Yulia Tymoshenko. The involvement of the EP was more than just a short term publicity stunt. Under the lead of former EP President Pat Cox and former Polish President Aleksandr Kwaśniewski, the EP set up a monitoring mission, which over the course of 18 months developed intense relations with the Ukrainian leadership and opposition, and managed to influence the EU's diplomatic course in the run-up to the Vilnius Summit. What has led the EP to set up its own diplomatic mission? To what extent were its actions coordinated with the Council of Ministers, the Commission, the EEAS or the EU memberstates? And did their manoeuvres support or rather distort the strategies of executive diplomats?

Conceptualising parliamentary diplomacy as a transnational, it is argued the EP is able to directly interact with external actors, in that way bypassing a polity's central foreign policy organs. In doing so, the EP's diplomacy could follow a supportive or competitive logic, either complementing the official executive foreign policy, or diverging from executive strategies by claiming autonomous diplomatic agency.

To uncover the presence and explanatory force of both logics, the article makes an indepth analysis of the EP's monitoring mission to Ukraine. 'After shortly outlining the conceptual framework and spelling out the two logics of the EP's parliamentary diplomacy, the case-study zooms in on the role of the EP during the Ukrainian crisis in the run-up to the Vilnius Summit. Next to the scrutiny of parliamentary records, EU institutional documents and newswires, the empirical part of the article is based on 20 semi-structured interviews with MEPs, officials of the EP, the EEAS, the European Commission, and the Council Secretariat. 


\section{The logics of parliamentary diplomacy: a framework for analysis}

This Working Paper (WP) conceptualises parliamentary diplomacy as a transnational phenomenon. Transnational relations are defined as 'regular interactions across national boundaries when at least one actor is a non-state agent or does not operate on behalf of a national government or an intergovernmental organization' (Risse-Kappen 1997, p. 3). Following Nye and Keohane, the transnational status of an actor is to be inferred from its behaviour, rather than from the formal role it occupies (Nye and Keohane 1971b, p. 331). This implies that, next to private non-governmental organisations, also subunits of government such as state agencies, bureaucracies, and in this case parliamentsii, could qualify as transnational actors. Indeed, such 'subunits of government may also have distinct foreign policies which are not all filtered through the top leadership and which do not fit into a unitary actor model' (Nye and Keohane 1971a, p. 731; see also Mansbach et al. 1976, p. 41; Josselin and Wallace 2001, p. 2-3). Parliamentary diplomacy is hence defined as the autonomous conduct of external relations by parliamentary actors through practices of communication, negotiation, mediation and representation, enabling it to conduct a distinctive foreign policy and to represent its polity in international affairs.

Traditionally, the literature on transnationalism has been 'engaged in the exercise of proving against a state-centered picture of world politics that transnational actors matter' (Tallberg and Jönsson 2010, p. 9), rather than exploring how states and IGOs might enable or constrain transnational actors, as well as vice-versa (Risse-Kappen 1997, p. 14). It is however the latter puzzle which forms the focus of the current WP, by asking how the EP relates with the EU executives in CFSP (i.e. the Council, the EEAS) in its conduct of parliamentary diplomacy.

Indeed, parliamentary diplomacy could be pursued in multiple ways, ranging from strong coordination with executive foreign policy, to a complete independent undertaking. It could be conducted in a spirit of mutual cooperation where parliamentary actors aim to facilitate the promotion of interests of the executive, but it may equally result in strategies of rivalry and impingement where the actions of parliamentary actors undermine the foreign policy goals of the executive.

This WP proposes that parliamentary diplomacy could in principle follow two different logics with regard to its relationship vis-à-vis the executive, either a supportive or a competitive one (see Table 18.1). On the one hand, parliamentary diplomacy could be driven by a demand of the executive to assist with the execution of certain foreign policy objectives, resulting in cooperative dynamics. On the other, the parliamentary actors may see parliamentary 
diplomacy as an opportunity to promote own foreign policy interests, resulting in a competitive logic. It should be stressed that, while the two logics are discerned for analytical reasons, it is not excluded that both logics may fluctuate from one to another.

\section{Supportive logic}

According to a first logic, parliamentary diplomacy is supportive as it is driven by a demand of the executive to assist with the execution of governmental foreign policy. Parliamentary actors accept the hierarchy or 'diplomatic lead' of the executive, inscribe themselves within a clearly pre-defined division of roles, and align and coordinate their interventions with the executive. From a governmental point of view, such type of parliamentary diplomacy would be considered as a type of 'track-two' diplomacy, in which 'any agency or entity other than a state or intergovernmental organisation [is involved] in diplomatic negotiations' (du Plessis 2007, p. 141).

A supportive logic arises from a context in which states have "become dependent on transnational organizations providing something' such as goods, services, information, knowhow or legitimacy (Nye and Keohane 1971b, p. 339; Tallberg and Jönsson 2010), and where parliamentary diplomacy could be seen as a response to such 'executive resource dependencies'. Parliamentary actors are able to provide resources that executives might be lacking at certain times (such as expertise, legitimacy, or privileged access to certain actors). Therefore, they are opted into the executive's implementation of foreign policy as they can be used as 'instruments for influence for use by some governments over others' (Nye and Keohane 1971b, p. 340). Executives therefore manipulate transnational actors as a more informal means of influence, either 'through control or willing alliance' (ibid., p. 341).

\section{Competitive logic}

A second logic of parliamentary diplomacy departs from the argument that some transnational actors 'are so powerful that they are able to pursue their interests outside the direct control of states, while at the same time sometimes involving governments in particular problems as a result of their activities' (Kegley and Wittkopf 1993, p. 204). Parliamentary actors might position themselves as autonomous actors in international politics which prefer to keep distance from executive diplomats. They do not accept a supportive role but rather strive for full operational independence, intervening regardless of the diplomatic presence (or deliberately chosen inaction) of the executive. As a crucial difference with the supportive logic, they do not act upon an invitation or demand of the executive, but to a certain degree claim diplomatic prerogatives for themselves with regard to a specific issue area or conflict. 
Such competitive role constellation could be the result of two factors. One the one hand, it could be linked to intrinsic motivations of parliamentary assertiveness (Auel and Christiansen 2015), where the external presence or visibility of parliamentary actors is likely to pay off in impact on government policies. Not only are parliamentarians better informed through external contacts; their external presence will incite governmental actors to embed their actions as much as possible within the executive diplomatic strategy. In this process, which is labelled here as 'foreign policy shaping', the EP thus seeks to strengthen its interinstitutional standing in the EU's foreign policy making, thereby affecting the degree of freedom of the Council of Ministers.

On the other hand, a competitive set-up could equally be the result of an external demand for parliamentary diplomatic involvement. Foreign actors, involved in a conflict, might call upon parliamentary envoys to mediate between conflicting parties. In such scenario, parliaments might decide to respond to such a demand and get involved, without much consultation with the domestic executive actors, and therefore potentially result in competitive dynamics.

Table 18.1. Logics of parliamentary diplomacy

\begin{tabular}{lll}
\hline & Supportive logic & Competitive logic \\
\hline Driver & Executive resource dependencies & $\begin{array}{l}\text { Foreign policy shaping, external } \\
\text { demands }\end{array}$ \\
\hline Relationship & Hierarchy: parliaments are co-opted & Autonomy: parliaments act on their \\
with & in executive diplomacy and invited to & own, without an invitation of the \\
executive & assist in foreign policy & $\begin{array}{l}\text { executive, in order to shape EU } \\
\text { foreign policy }\end{array}$ \\
\hline Role & Dimplementation & Claiming the prerogative, \\
constellation & are outsourced to the EP & parliamentary actors engage in the \\
& & work of traditional diplomats \\
\hline
\end{tabular}

\section{Case-study: the Ukrainian crisis and the Cox-Kwaśniewski mission}

This section takes stock of the EP's Monitoring Mission (hereafter EPMM), launched in May 2012 and dissolved in November 2013. It retraces the diplomatic steps taken by the EP by focusing on three different stages of the mission: the context in which it originated, its subsequent alterations throughout the mediation process, and its standing at the end phase. It is examined to what extent EP's autonomous diplomatic agency could be characterised as 
a supportive phenomenon, focusing on implementing and defending the Council's CFSP, or as a competitive phenomenon, aiming at shaping the EU's foreign policy. Finally, an assessment of the EP's relative significance is made by situating its agency in a broader interinstitutional context.

\section{Retracing the origins of the Cox-Kwaśniewski mission}

\section{A context of deadlock}

Negotiations for an Association Agreement (AA) in between the EU and Ukraine were launched in 2007, under the auspices of former President Yushchenko. While President Yanukovych, assuming office in 2010, continued the course of European integration set by his predecessors, domestic developments increasingly threatened the eventual signing of the agreement. His authoritarian leadership, and most notably the issue of 'selective justice', increasingly created doubts in Brussels on whether Ukraine was ready to become politically and economically associated with the EU. Particularly the sentencing and imprisonment of Tymoshenko in October 2011, caused considerable controversy among EU-circles and was responded by postponing the conclusion of the AA.

Although in April 2012 negotiations were officially concluded, prospects for a swift and uncontested signing of the treaty further decreased. With Tymoshenko's imprisonment being increasingly politicized and mediatized, the European Commission decided to cancel its attendance to the UEFA Euro-2012 football championship games co-hosted in Ukraine, soon to be followed by other EU member-states such as Germany, the Netherlands, Austria and Belgium.

In this context, the EP decided to set up a Monitoring Mission (hereafter: EPMM), tasked with 'monitor[ing] court proceedings involving the imprisoned former Ukrainian Prime Minister Yulia Tymoshenko' (European Parliament 2012), in that way hoping to find a way out for the Ukrainian impasse. The EPMM was headed by two special envoys: Pat Cox, former MEP and EP President, and Aleksander Kwaśniewski, former President of Poland. The envoys were guaranteed access to all documents relevant to her case, as well as to the involved lawyers and prosecutor. They would be provided legal and logistical support from the EP Secretariat.ii

The mission was launched at a time when EU member-states were increasingly divided over the Ukrainian dilemma. More specifically, western-European member-states such as Germany, France, Spain, Netherlands and Italy largely took a hard line on the issue, prioritizing the rule of law and good neighbourly relations with Russia (Interview 20). They 
therefore conditioned their signature for the AA on the fate of Tymoshenko. Poland, the Baltic states and Sweden, joined by the European Commission and the EEAS, above all prioritized the signing of the AA, fearing a 'Belarusian scenario' (Pastore 2014; Vandecasteele 2014, p. $51-52)$.

\section{An autonomous and competitive process}

From the very start, there were indications that the EP was profiling itself as an autonomous actor and a policy-shaper, rather than being opted into the executive's diplomatic game. The parliamentary monitoring mission was a personal initiative of EP President Martin Schulz, after he met Ukrainain Prime Minister Azarov in Brussels on 16 May 2012 (Conference of Presidents 2012a). During the meeting, Schulz negotiated the basic terms of the mission with Azarov, without having held any prior consultations with the Council, the EEAS or the European Commission (EUobserver 2012).

The monitoring mission therefore appeared to be a deliberate attempt to redefine the EU's approach, i.e. to shape EU foreign policy through bypassing the executive actors and instead engaging directly with Ukrainian counterparts. Interestingly, the launch of the mission was decided upon two days after the May 2012 EU's Foreign Affairs Council (FAC) was unable to produce a clear position on the Ukrainian dossier. ${ }^{i v}$ As an EP official illustrates, Schulz' démarche was strongly triggered by a feeling of discontent with the Council's foreign policy strategy, or rather the lack thereof:

What we saw in the EP was a total lack of strategy and understanding by the other EU institutions. Yanukovych was cornered too much - he didn't want to release Tymoshenko. EU member states were divided on what to do: to engage or to isolate. This is the moment when Schulz intervened. He argued we needed to redefine the situation. (...) The day after we had [HR/VP] Ashton on the line asking how it was fitting in "their strategy". Schulz replied that there was no "strategy", so that they should let his mission at least try. (Interview 5) 


\section{The EPMM's metamorphosis}

\section{A classic example of mission creep}

Scrutinising the mandate amendments further confirms that the EPMM foresaw itself a role greater than merely acting within the margins of the Council's foreign policy lines. The original mandate of a two week mission overseeing Tymoshenko's cassation appeal on the $26^{\text {th }}$ of June was amended very soon. A first amendment came during the first visit of the envoys to the Ukrainian President and Prime Minister on the $11^{\text {th }}$ of June (EurActiv 2012; Kwaśniewski 2012). Suddenly, the cases of Tymoshenko's former colleagues Lutsenko (ex-minister of interior) and Ivashchenko (ex-acting Defense Minister), as well as monitoring the preparations for the October 2012 parliamentary elections, were added to their task list (Interfax 2013a). Polish MEP Siwiec declared at the time that Cox and Kwaśniewski purposefully travelled to Ukraine 'in order to "extend their mandate" so that they [could] talk about the political situation in Ukraine before the elections' (Siwiec 2012).

In the end, the EPMM lasted more than 18 months, following a pattern of six subsequent mandate extensions, approved by the EP's Conference of Presidents. During the first months, the mission still aimed to maintain a low profile by strictly focusing on Tymoshenko's court proceedings and detention conditions. President Schulz insisted on naming the EPMM a 'humanitarian mission', which should refrain from defining what the political conclusions would be in light of the pending AA signature (Conference of Presidents 2012c). Gradually, however, the mission became more prominent and political in nature. On the one hand, this can be explained by a sense of increased confidence after the release of Ivashchenko in August 2012, which also increased its legitimacy in the eyes of the executive. On the other hand, it was also due to Kwaśniewski's active role (Interviews 3, 19). For example, at the EP's Conference of Presidents in July 2012, Schulz criticized Kwaśniewski who had given media interviews on the upcoming parliamentary elections in Ukraine, stating 'it was not relevant to the specific mandate given to [them]' and therefore 'requested $\mathrm{Mr}$ Kwaśniewski to refrain from further comment in this direction' (Conference of Presidents 2012b). The EP President conveyed a similar message two months later (Conference of Presidents 2012c).

By January 2013, the EPMM had been charged with tasks that were highly politicised. In addition to the cases against Tymoshenko, Lutsenko and Ivashchenko, the EPMM now focused on another two judicial cases, next to the reform of the electoral legislation, the adoption of new Criminal Procedural Code and the reform of the Public Prosecutor's Office (Kwaśniewski 2013). At this moment, Kwaśniewski already declared that 'the mission must be 
extended until its main goals are fulfilled', adding that 'it currently seems that a borderline date has been set for November 2013' (BBC 2012). He thereby hinted at the Vilnius EaP Summit, which the EU meanwhile presented as the moment of truth for the AA. An EEAS official admitted: 'in the end the mission went much further than what [the member-states] expected. They didn't think this was going to be a mission travelling 17 times to Ukraine' (Interview 19).

\section{... facilitated by the executive}

The release of former Defense Minister Ivashchenko led to an attitude shift on the sides of the Commission, the Council and the EEAS, who from then on sought to embed the EPMM within their foreign policy strategy (Interviews 5 and 20). Indeed, signals of approval and endorsement were given in press declarations of Commissioner Füle and HR/VP Ashton (European Commission 2013a; European Commission 2013b). Especially the support of Foreign Affairs Council is noteworthy, when, in its December 2012 conclusions, it commended 'the efforts undertaken by the European Parliament's monitoring mission to Ukraine headed by former Presidents Cox and Kwaśniewski' (Council 2012b). In this way the Council formally recognised the EPMM and encouraged it to continue its work.

Remarkably however, the EPMM interpreted the Council Conclusions as a mandate expansion, broadening its focus to the wider issue of 'selective issue'. The EPMM later on reported that 'the mission's focus remains the achievement of the necessary conditions for it to report full compliance with the criteria set by the Foreign Affairs Council of the EU in December 2012 for the signing of the Association Agreement with Ukraine' (EU Delegation Ukraine 2013) and that, based on this, 'the monitoring mission was mandated to deal solely with the aspect of selective justice in the Ukraine' (Conference of Presidents 2013c). EEAS and Council officials called the EP's reading and instrumentalisation of the Council Conclusions 'remarkable' and 'highly creative', stressing that the paragraph did not provide a real mandate for the mission (Interviews 17, 18). In short, while especially the Council's endorsement indicates that the EP was opted into the EU's official diplomacy, it is clear the EP rather invited itself to the party.

\section{The EPMM on the eve of the Vilnius Summit: a pivotal player}

By the time the EPMM had neared its final stage, it revealed itself as a strong policy shaper. Four arguments support this claim: it had managed to condition the $A A$ to the fate of Tymoshenko, it had become a crucial intermediary on the ground, it determined the way forward at crucial moments, and finally, it had to judge whether conditions were met for the AA to be signed. 
The rationale behind the EP's decision to monitor the trial of Tymoshenko was not only defined by a divided Council of Ministers. It should equally be seen as an internal response to the deteriorating relations in between the EPP and S\&D political groups during the spring of 2012 . With Tymoshenko's Batkivschyna party being a member of the EPP, and Yanukovych' Party of Regions having signed a cooperation agreement with the S\&D group, the EP's two main party groups found themselves politically associated with the two conflicting sides in Ukraine. Given the alliances, the EPP rather unconditionally supported Tymoshenko and asked for her immediate release, in turn strongly irritating the socialists who pointed at her past wrongdoings (Interviews 8, 9, 12). President Schulz therefore decided to appoint two unelected envoys on behalf of the EP, in an attempt to defuse the in-house conflict (Interview 5).

The consequence, however, was that with its mission the EP de facto further cemented the dependence of the EU's signature on the fate of Tymoshenko, a pill too bitter to swallow for Yanukovych, as became clear afterwards. As an EEAS official argued:

The EP's approach differed from ours. They really focused their mission on the monitoring of Yulia Tymoshenko's trial. This was an EP idea, with a clear partypolitical perspective of the EPP and S\&D. We [the EEAS] would have handled it differently. (...) I think it became clear that it would have been better if nobody had visited Yulia Timoshenko. (Interview 19)

\section{A decisive actor on the ground}

The EPMM established itself as a crucial contact point on the ground for the issue of selective justice, negotiating with the authorities on behalf of the EU. The mission was said to be crucial for the preservation of communication in between Brussels and Kyiv, and for the EU to have influence over Ukraine (Euractiv 2013). The Polish ambassador to Ukraine stated that: 'there is only one structure in charge of the issue [of selective justice] - the Cox-Kwasniewski mission. As far as I am concerned, no other consultations are being held, and I think no other consultations should be held' (Interfax 2013c). Even for the United States ambassador, the EPMM had become 'the main channel of communication with the Ukrainian government on this issue [of selective justice]' (Interfax 2013b).

Data provided by the Cabinet of the EP President on the nature, number and scope of interactions indicate the EPMM held numerous meetings with Ukraine's political elite of Ukraine. Next to holding 68 telephone calls with the authorities and opposition, the mission 
travelled to Ukraine no less than 27 times, corresponding to 75 days of meetings. They held 18 meetings with President Yanukovych (lasting more than 50 hours), 25 meetings with Prime Minister Azarov, four meetings with the Prosecutor General of Ukraine and three meetings with the Foreign Minister. ${ }^{v}$ Meetings were often directly focused on negotiating the substance of draft laws on judicial reform. This further shows that the EPMM was replacing rather than complementing the core work of executive diplomats. An EP official argued that especially on aspects of judicial reform 'the Commission and the EEAS were constantly knocking on our door, desiring to know what had been said, by whom it had been said, what had been promised and so on' (Interview 14).

\section{Determining the way forward}

Being the contact point on the ground, the EPMM was able to define the diplomatic strategy at crucial moments and to co-determine the state of play at the Vilnius summit. Backed by the Commission and the German Chancellor, Cox and Kwaśniewski took the initiative of sending a letter to President Yanukovych on 4 October 2013, proposing a 'partial pardon'vi on 4 October 2013 for Tymoshenko (Conference of Presidents 2013c). As Yanukovych was not willing to accept the proposal, he counter-offered to have the Verkhovna Rada (the Ukrainian parliament) voting on a law that would permit the treatment abroad of convicted persons on health and humanitarian grounds. vii Although being unacceptable for the EU, Cox and Kwaśniewski convinced all parties to accept Yanukovych' proposal, as they realised that the Ukrainian President was not willing to sign the AA anymore but did not want to take the blame for it. The strategy of Cox and Kwaśniewski was therefore to call Yanukovych' 'bluff' in order 'to expose him fully to his own lies' (Interview 5).

This compelled Yanukovych to undergo a vote in the Ukrainian Verkhovna Rada, where crucial amendments got voted down by his own Party of Regions (while the opposition voted in favour), in that way fully discrediting the President and his government for failing to live up to their own commitments. In short, the EPMM strongly influenced the end-game at the eve of the Vilnius Summit. It opted for a strategy of collision with Yanukovych, instead of postponing the signing of the AA as he had asked for since the beginning of November. The confrontational climate was even further exacerbated when Kwaśniewski declared before the international press that the signing of the AA had become 'a geopolitical battle which will decide the future of the whole of Europe, Ukraine, the EU and Russia' (Tass 2013). 
Finally, the EP presented its own mission as being crucial for judging and establishing the conditions that would allow the signing of the AA, and also explicitly justified the further extension of the EPMM on that premise (see Conference of Presidents 2013a). By October 2013 the EP President stated 'that the Council would base [its] decision regarding the selective justice criteria on the findings of the Cox-Kwaśniewski mission' (Conference of Presidents 2013b), completely contradicting his earlier statements made in the summer of 2012. Swedish foreign minister Carl Bildt endorsed the EPMM by explicitly stating that 'the EU will not give the green light without the green light from the Cox-Kwasniewski mission' (Interfax 2013d).

In short, the above clear shows how the EPMM de facto modified the bilateral relations in between the EU and Ukraine, corresponding to a competitive logic. In that way the EP 'alter[ed] the choices open to statesmen and the costs that must be borne for adopting various courses of actions' as Nye and Keohane (1971a, p. 724-725) have put it.

\section{A permissive context for parliamentary diplomacy}

In order to fully understand how the impressive growth of the EPMM's role was possible, one also needs to take into account the position and behaviour of the other EU institutions. Indeed, multiple interviews indicate that the EP's prominent diplomatic involvement was strongly facilitated by a permissive institutional context.

On the one hand the Council could or did not want to play its role, thereby 'creating a window of opportunity for the EP to jump in' (interview 19). First, member-states remained divided over the issue throughout the eighteen months of the EP's monitoring mission. Some remained undecided on the $A A$ until the EaP Summit itself, being unable to give a mandate to sign the agreement on behalf of the EU (Youngs and Pishchikova 2013, p. 4; Interview 20). Given this stand-off, the EPMM was confronted with little to no resistance from the Council.

Second, neither did the EEAS manifest itself very prominently as leading mediating actor on the ground. HR/VP Ashton did not travel a single time to Ukraine in order to force an agreement with Yanukovych on the AA. Multiple interviews viii indicate the HR/VP showed a lack of interest for the Ukrainian file, preferring high-level diplomacy on Iran's nuclear program, Middle Eastern dialogues or the Serbian-Kosovar reconciliation efforts.

Moreover, Ashton's inattention for Ukraine cleared the way for Commissioner Füle to take over the political leadership on the dossier, while also allowing him to collaborate intensively with the EP on it (Interview 6). Indeed, after an initial period of doubt and hesitation, the Commission fully supported the EPMM. An involved Commission official claimed that the widening and the deepening of the EPMM's mandate was first and foremost possible because 
of their active backing (Interview 20). Further indicative of the strong and collaborative ties with the Commission was the creation of the so-called 'Vilnius Group'ix within the EP, bringing together the Commissioner with the representatives of the political groups as well the rapporteur on the EaP, intended to exchange information and to align positions.

Finally, the overall converging foreign policy goals (clearing the way for the AA to be signed) of the Council and the EPMM, made the mission according to an EEAS official, also 'instrumental for the Council' (Interview 6; see also Interviews 2,4). It therefore seems that the EP's agency was to a certain extent also tolerated, since it was not directly harming the interests of the member-states. Whereas in the beginning the Council was very suspicious, 'in the end they took it very pragmatic, and even encouraged the EP to act' (Interview 3).

\section{Conclusion}

This WP has shed light on the EP's parliamentary diplomacy towards Ukraine in the run-up to the November 2013 EaP Summit, in particular by studying how its involvement the EU's CFSP related to the official 'executive' diplomacy of the Council and the EEAS. The analysis has shown that, in its origins, the EP's monitoring mission was a clear type of parliamentary diplomacy that took a competitive character vis-à-vis the executive, triggered by the willingness to influence or shape the EU's foreign policy. Following subsequent mandate expansions and diplomatic démarches, the EP eventually even took over the lead on the overall justice and electoral reform in Ukraine, being in constant contact with both the Ukrainian leadership and opposition, while initially only being tasked to monitor a single court hearing on Yulia Tymoshenko.

That having said, it is clear that the EPMM clearly benefited from a permissive institutional context, in which the Council offered limited to no resistance towards its increased prominence. Indeed, exactly due to a divided and undecided Council, the EPMM's move to the diplomatic arena went rather uncontested. Even more, the Commission put its weight behind the mission, thereby further stimulating its free-wheeling behaviour.

In short, the current case study has found parliamentary diplomacy and executive diplomacy to be in competition with each other on actor-level (i.e. claiming the diplomatic prerogative). Future research could benefit from exploring whether competitive parliamentary diplomacy is able to function under more challenging circumstances of a unitary executive, i.e. a homogenous Council position, and in a context of clear foreign policy divergence. 


\section{Notes}

'As this contribution is primarily occupied with studying the diplomatic agency of the EP, it
refrains from making a broader evaluation of the monitoring mission in the overall EU-
Russia-Ukraine relations. For such analysis, see Nitoiu and Sus (2017).
ii For a similar reasoning, see Keck and Sikkink, who name 'parliamentary branches of
government' as a potential type of transnational actors (1999, p. 92).

iii The two envoys were supported by an advisor from the cabinet of the EP president, two policy advisors from the Parliament's Secretariat, and two lawyers.

iv The FAC did not adopt any conclusions on Ukraine, and therefore exchanged views 'on the developments in

Ukraine and on next steps concerning the EU-Ukraine Association Agreement' during their lunch (Council of Ministers 2012a).

v Also on the EPMM's meeting list were: the Ukrainian Speaker of the Rada (3 meetings), the Secretary of the National Security and Defense Council (13 meetings), various opposition leaders (in total 21 meetings), the three former Ukrainian presidents (4 meetings), 18 NGOs (6 meetings) and the US ambassador (13 meetings). At the EU-side, the mission met the EU-28 Heads of Mission (16 meetings), Commissioners Barroso, De Gucht and Füle (10 meetings), the Lithuanian presidency (6 meetings) and leading EEAS officials (5 meetings).

vi In the letter the envoys proposed to lower Mrs. Tymoshenko's sentence from seven to two years, and to allow her to go to Germany for medical treatment.

vii This would however not grant a reduction of Tymohsenko's sentence, disabling her to stand for the presidential elections of 2015.

viii Interviews 3, 4, 5, 6, 7, 14, 16, 17, 20.

ix Vilnius Group meetings were launched by Commissioner Füle nine months before the Vilnius summit and have continued to take place ever since. 


\section{Interviews}

Interview 1: EP Official, 15.01.2014, Strasbourg.

Interview 2: EP Official, 19.05.2015, Brussels.

Interview 3: EP Official, 05.06.2015, Brussels.

Interview 4: EP Official, 24.09.2015, Brussels.

Interview 5: EP Official, 29.09.2015, Brussels.

Interview 6: EEAS official, 30.09.2015, Brussels.

Interview 7: Member of European Parliament, 30.09.2015, Brussels.

Interview 8: Two political group advisors on foreign affairs, 01.10.2015, Brussels.

Interview 9: Political group advisor on foreign affairs, 02.10.2015, Brussels.

Interview 10: MEP Assistant, European Parliament, 02.10.2015, Brussels.

Interview 11: EP Official, 07.10.2015, Brussels.

Interview 12: Political group advisor on foreign affairs, 09.10.2015, Brussels.

Interview 13: Member of European Parliament, through e-mail exchanges on 24.09.2015 and 15.10.2015.

Interview 14: EP Official, 12.11.2015, Brussels.

Interview 15: Former EEAS official, 27.11.2015, Brussels.

Interview 16: EEAS official, 14.12.2015, Brussels.

Interview 17: EEAS official, 02.02.2016, Brussels.

Interview 18: Two officials of the Council Secretariat, 16.02.2016, Brussels.

Interview 19: EEAS official, 05.10.2016, Brussels.

Interview 20: former European Commission official, 25.10.2016, Prague.

\section{References}

Auel, Katrin, and Thomas Christiansen (2015), 'After Lisbon: National Parliaments in the European Union', West European Politics, 38 (2), 261-81.

BBC (2012), 'Former Polish leader urges European Parliament to extend Ukrainian mission', BBC Worldwide Monitoring, 11 January, retrieved through Lexis Nexis database.

Council of Ministers (2012a), Conclusions of the 3166th Foreign Affairs Council Meeting, Brussels, 14 May 2012.

Council of Ministers (2012b), Conclusions of the 3209th Foreign Affairs Council Meeting,

Brussels, 10 December 2012.

du Plessis A. (2007), 'Foreign Policy and Diplomacy', in PJ McGowan, S Cornelissen and P Nel (eds), Power, Wealth and Global Equity: An International Relations Textbook for Africa. Cape Town: UCT Press, 119-147. 
EU Delegation Ukraine (2013), 'The statement of Presidents Cox and Kwasniewski', 21

October, accessed $19 \quad$ May 2015 at: http://eeas.europa.eu/delegations/ukraine/press_corner/all_news/news/20.

EUobserver (2012) 'Ukraine firms up promise on Tymoshenko monitoring', 22 May, accessed 16 June 2015 at https://euobserver.com/foreign/116339.

EurActiv (2012) 'Kyiv welcomes EU monitors in Tymoshenko trial', 8 June, accessed 3 March 2015 at: http://www.euractiv.com/europes-east/kyiv-welcomes-eu-monitors-tymoshnews-513213.

Euractiv (2013) 'Special EU mission to Ukraine wins praise, extended term', 19 April, accessed 8 October 2014 at: http://www.euractiv.com/europes-east/special-eu-mission-ukrainewins-news-519230.

European Commission (2013a), 'Joint Statement by EU High Representative, Catherine Ashton, and Commissioner Stefan Füle on the review by Ukraine's Higher Specialized Court for Civil and Criminal Cases in the case of Yuriy Lutsenko', 4 April, accessed 14 October 2014 at: http://europa.eu/rapid/press-release_MEMO-13-305_en.htm.

European Commission (2013b), 'Joint Statement by EU High Representative, Catherine Ashton, and Commissioner Stefan Füle on today's judgement by the European Court of Human Rights in the case of Tymoshenko v. Ukraine', 30 April, accessed 14 October 2014 at: http://europa.eu/rapid/press-release_MEMO-13-394_en.htm.

European Parliament (2012), 'Cox, Kwasniewski to monitor Tymoshenko appeal on behalf of EP', Press Release, 6 June 2012, available at the EP website.

European Parliament Conference of Presidents (2012a), Minutes of the Meeting of 16 May 2012, Brussels.

European Parliament Conference of Presidents (2012b), Minutes of the Meeting of 5 July 2012, Strasbourg.

European Parliament Conference of Presidents (2012c), Minutes of the Meeting of 6 September 2012, Brussels.

European Parliament Conference of Presidents (2013a), Minutes of the Meeting of 6 February 2013, Strasbourg.

European Parliament Conference of Presidents (2013b), Minutes of the Meeting of 3 October 2013, Brussels.

European Parliament Conference of Presidents (2013c), Minutes of the Meeting of 15 October 2013, Brussels.

Interfax (2013a), 'Cox, Kwasniewski to observe court proceedings against Lutsenko, Ivaschenko, preparations for elections in Ukraine', Ukraine General Newswire, 6 June, retrieved through Lexis Nexis database. 
Interfax (2013b), 'US ambassador: Tymoshenko case a matter of principle for Washington', Ukraine General Newswire, 18 September, retrieved through Lexis Nexis database. Interfax (2013c), 'No other consultations held on Tymoshenko issue outside Cox-Kwasniewski mission, says Polish ambassador', Ukraine General Newswire, 15 October, retrieved through Lexis Nexis database.

Interfax (2013d), 'EU wont' sign association agreement with Ukraine if Cox-Kwasniewski doesn't give green light to this - Swedish Foreign Minister Bildt', Russia \& CIS Diplomatic Panorama, 23 October, retrieved through Lexis Nexis database.

Josselin D and Wallace W. (2001), 'Non-state Actors in World Politics: a Framework', in D Josselin and W Wallace (eds), Non-state Actors in World Politics, Hampshire: Palgrave Macmillan, pp. 1-20.

Keck ME and Sikkink K. (1999), 'Transnational advocacy networks in international and regional politics', International Social Science Journal, 51 (159), 89-101.

Kegley CW and Wittkopf ER. (1993), World Politics: Trend and Transformation, Hampshire: Macmillan Press.

Kwaśniewski A. (2012), 'Former Polish President Aleksander Kwasniewski and the former head of the European Parliament Pat Cox will be European Parliament observers on Yulia Tymoshenko trials', 7 June, accessed 18 October 2014 at http://kwasniewskialeksander.pl/english/news/former-polish-president-aleksanderkwasniewski-and-the-former-head-of-the-european-parliament-pat-cox-will-beeuropean-parliament-observers-on-yulia-tymoshenko-trials.

Kwaśniewski (2013), 'EP Monitoring Mission to Ukraine', 15 October, accessed 18 October 2014 at http://kwasniewskialeksander.pl/english/news/ep-monitoring-mission-toukraine-key-observations-to-the-conference-of-presidents-of-the-europeanparliament

Mansbach RW, Ferguson YH and Lampert DE. (1976), Web of World Politics: Non-state Actors in the Global System, Englewood Cliffs: Prentice Hall.

Nitoiu C and Sus M. (2016), 'The European Parliament's Diplomacy - a Tool for Projecting EU Power in Times of Crisis? The Case of the Cox-Kwasniewski Mission', JCMS: Journal of Common Market Studies, 55 (1), 71-86.

Nye JS and Keohane RO. (1971a), 'Transnational Relations and World Politics: A Conclusion', International Organization 25 (3), 721-48.

Nye JS and Keohane RO. (1971b), 'Transnational Relations and World Politics: An Introduction', International Organization 25 (3), 329-49.

Pastore G. (2014), 'The EU-Ukraine Association Agreement prior to the Vilnius Eastern Partnership Summit', Baltic Journal of European Studies, 4 (2), 5-19. 
Risse-Kappen T. (1997), 'Bringing transnational relations back in: introduction', in T RisseKappen (ed), Bringing Transnational Relations Back in. Non-State Actors, Domestic Structures and International Institutions, Cambridge: Cambridge University Press, 336.

Siwiec, M. (2012), 'The difficult mission', blog article, 7 June, accessed 19 October 2014 at: https://mareksiwiec.blogactiv.eu/2012/06/07/the-difficult-mission/.

Tallberg J and Jönsson C. (2010), 'Transnational Actor Participation in International Institutions: Where, Why, and with What Consequences?', in J Tallberg and C Jönsson (eds), Transnational Actors in Global Governance. Patterns, Explanations and Implications, Hampshire: Palgrave Macmillan, 1-21.

Tass (2013) 'Timoshenko urges EU to sign AA with Ukraine without preconditions', 27 November, accessed 18 October 2014 at http://tass.ru/en/world/709334.

Vandecasteele B. (2014), 'Influence of the Lithuanian presidency of the EU council on EU relations with countries of the Eastern partnership', Lithuanian Foreign Policy Review, 31, 37-66.

Youngs R and Pishchikova K. (2013), 'Smart Geostrategy for the Eastern Partnership', Brussels: Carnegie Europe. 